\title{
THE RELATIONSHIP BETWEEN ORGANIZATIONAL INNOVATIONS, INTERNAL SOURCES OF KNOWLEDGE AND ORGANIZATIONAL PERFORMANCE
}

\author{
Rim Maâlej Ben Zaied ${ }^{1}$ and Hanène Louati ${ }^{2}$ and Habib Affes ${ }^{3}$ \\ ${ }^{1}$ Research Laboratory in Information Technology, Governance and Entrepreneurship, \\ FSEGS University, Sfax, Tunsia \\ ${ }^{2}$ Research Laboratory in Finance, Governance and Accounting, FSEGS University, Sfax, \\ Tunisia \\ ${ }^{3}$ Department of Business administration, Jizzan University, Arabia Saoudit
}

\begin{abstract}
Management research considers knowledge as one of the first sources of competitiveness of the company. This observation is at the origin of development in recent years, the Knowledge-Based View (Grant, 1996), resulting from the resource-based perspective approach.

This research examines the importance of internal sources of knowledge and its relationship with organizational innovation and organizational performance. We did this research on a sample of 200 Tunisian companies operating in different sectors. Our study was built mainly on the basis of quantitative method. The data collection method is the questionnaire as part of a hypothetical-deductive approach and the mode of administration is self-administered survey and e-mail survey. The empirical verification of the assumptions of this research has led us to confirm the relationship between internal and external sources of knowledge with organizational innovation and organizational performance and to infirm the relationship between organizational innovation and organizational performance.
\end{abstract}

\section{KEYWORDS}

Organizational innovation, internal sources of knowledge, organizational performance.

\section{INTRODUCTION}

Many international studies underline that innovation in the organization of companies, knowledge management, and implication of the workers often make a decisive comparative advantage (Gerard and Vendramin; 2006).

The organizational innovations are considered as a key of success in the development of new products, new services and more successful processes.

Internal knowledge is defined as "the body of knowledge that the company creates within its borders. This definition includes explicit and tacit knowledge and organizational learning stored in the organizational routines, culture and strategy "(Crossan et al 1999; Nonaka 1994). In short, internal knowledge includes "the knowledge within the firm, codified as patents, trademarks and copyrights, as well as the tacit knowledge of the business such as routines and culture."Regarding the relationship between organizational innovation and organizational performance, the results of 
this research are often mixed. They vary between a positive and negative relationship (Legge 1995; Montgosay and Lieberman 1998).

In addition, the concept of performance is still poorly defined, vocabulary specialists is no unanimous. Indeed, many researchers find it difficult to agree on its meaning. It is apparent, moreover, with several neighboring concepts such as efficiency and effectiveness. It remains that performance remains a medium that is often defined by criteria such as represented by the theorists and practitioners of the performance and its measurement built (Igalens et al 2003; Wu 2006).

This aims to explain the relationship between the three variables; internal sources of knowledge, organizational innovation and organizational performance and to test a model which includes the relationship in Tunisian firms. We did this research on a sample of 200 Tunisian companies operating in different sectors. Our study was built mainly on the basis of a quantitative method. The paper opted for an exploratory study using the software SPSS and AMOS. The empirical verification of the assumptions of this research has led us to confirm the relationship between the internal sources of knowledge, organizational innovation and organizational performance.

\section{REVIEW OF LITERATURE}

\subsection{Internal sources of management}

Internal knowledge is one of the sources of knowledge management that have been enjoyed in the literature (Ahuja and Lampert2001; Katila 2002; Phene et al2006; Rosenkopf and Nerkar 2001; Nonaka and Martinet 2003)).

Nonaka and Takeuchi (1997) challenge especially theorists of organizational learning, based on the work of (Argyris and Schon 1978) show that companies can manage themselves a "singleloop learning" but that "the learning loop double "requires outside intervention. According to them, knowledge creating company is also able to change the basic rules of interaction between tacit and explicit knowledge.

Internal knowledge contains capacities and rules which cannot be expressed. It is generated by the learning process through practice and use and defined as "the body of knowledge that the company creates within its borders. This definition incorporates explicit and tacit knowledge as well as organizational learning stored in the routines of the organization, culture and strategy "(Crossan et al 1999; Nonaka 1994). In short, internal knowledge includes "the knowledge within the firm, codified by patents, trademarks and copyrights, as well as the tacit knowledge of the business such as the routines and culture".

\subsection{Organizational innovation}

Many researchers are interested in the study of organizational innovation (Dozi 1988; Teece, 1989; Utterback and Abernathy 1975; Dewar et Dutton 1986; Ettlie, Bridges et O'Keffe 1984; Freeman 1992; Zaltman Duncan \& Holbek 1973; Oslo Manual of the OECD 2005).

The organizational innovation is the introduction of new organizational business management methods in the workplace and / or the relationship between a company and external agents (Hamel 20062007 2009). According to (Gunday et al 2011), the organizational innovations are strongly linked with all administrative efforts to renew organizational routines, procedures, mechanisms, systems, etc.. and in order to renew teamwork, sharing of information, coordination, collaboration, learning and innovation. The organizational innovation is considered a source of sustainable competitive advantage (Mol et Birkinshaw 2009).Also, the organizational innovations 
are strongly associated with all administrative efforts to renew organizational routines, procedures, mechanisms, systems, etc. and in order to promote teamwork, sharing of information, coordination, collaboration, learning and innovation (Gunday 2011). As regarded by a growing body of researchers innovation is a catalyst of growth in business and economy. Luecke \& Katz (2003, p.2) refers to innovation as 'the introduction of a new thing or method. Innovativeness refers to 'a firm's capacity to engage in new enterprise that is, introduction of new processes, products, or ideas in the organization' (2004, p. 429). This capacity to innovate is among the most important factors which influences the business performance and as such, innovativeness is amongst the unique culture which embeds in the tangible and intangible resources leading a firm towards successful business performance.

\subsection{Organizational performance}

The performance is far from being a simple phenomenon; it is a complex and multidimensional concept (Cameron 1986; Chakravarthy 1986; Venkatraman et Ramanujam 1986). Cameron (1986) states that organizational performance is inherently paradoxical because, from a given perspective, it may indicate a good performance, whereas from another perspective, it might indicate otherwise. In addition, individuals may have preferences on the most relevant aspects to define and evaluate performance (Zammuto, 1984) and, consequently, they may disagree on the measures to be used, the level of importance of assigned indicators, and how to interpret the results.

Organizational performance is "the capacity of an organization to identify and implement the appropriate strategies in the context of the objectives it pursues." (Bouquin 1997).

The factors of organizational efficiency are:

The respect for the structure published by the direction of the company.

$>$ The relations between the services: the concern of management is to reduce or resolve conflicts that may occur between the services and can challenge the necessary coordination efficiency.

$>$ The quality of the circulation of information: information is an integral part of the organization; therefore companies should be on the lookout for all the information. They also need to transmit it as soon as possible to make quick decisions which requires being in a state of constant surveillance and having tools to process and disseminate information.

$>$ The flexibility of the structure: in the context of a dynamic environment, structures must have a flexible character. The system should encourage the participation in the decision making, the employee turnover and the multilateral communication.

\section{HYPOTHESIS}

Our research aims to diagnose the relationship between organizational innovation and organizational performance. As illustrated in the research model, we assume that there is a relationship between organizational innovation and organizational performance.

\subsection{The relationship between internal sources of knowledge and organizational innovation}

Knowledge and innovation are closely linked. To innovate, the company has to rely on its internal knowledge bases, to both benefit from them and incorporate the information and the external knowledge. Now, knowledge is no forgotten as a result of innovation, but as an essential element of the capacity of the firm to innovate. 
According to Nonaka and Takeuchi (1997) "Understanding how organizations create new products, new methods and new organizational forms is important. However there is still a basic need to understand how organizations create new knowledge that makes these designs possible". Internal knowledge seems important for "innovation-generating organizations" (Damanpour et al., 2006), and is considered as a basis for the learning process leading to innovation (Lichtenthaler, 2009).

$\mathrm{H}(1)$ : There is a positive relationship between internal sources of knowledge and organizational innovation.

\subsection{The relationship between internal sources of knowledge and organizational}

The internal sources of knowledge consist of production and knowledge sharing within the company (Lee et al 1999).

The debates focused on the importance of inter-organizational and network resources as a source of relationships, knowledge and sustained performance for the companies. However, the internal network is potentially an equal important source of knowledge that personal networks within the company are often the first point of contact for the employees. According to studies by Soo et al (2002), professional service organizations revealed that employees largely depend on their personal networks for information and knowledge. Indeed, the interaction between internal and external business and is important in the process of innovation.

$\mathrm{H}(2)$ : There is a positive relationship between internal sources of knowledge and organizational performance.

\subsection{The relationship between organizational innovation and organizational performance}

The literature between innovation and organizational performance is not announced in the literature.

The literature develops innovation as a process in a variety of ways (Damanpour and Gopalakrishnan, 1998; Damanpour et al, 1989; Knight, 1967; North, Rogers, 1995; Thompson, 1965; Wolfe, 1994). Since the early work of Schumpeter (1934), innovation has been known as a key element of dynamic competition and market efficiency.

Therefore, the innovative companies develop faster, more efficiently and more profitable than non-innovative ones. That is why profitability can be defined as "the degree to which some financial indicators of the organization by increasing or decreasing compared to previous experiences or against a target" (Morin et al.1994).

"Organizational innovation also influences the performance of the company's quality of work, information exchange, capacity of learning and the use of new knowledge and technologies. It involves the implementation of new methods of organization of the routines and the procedures of execution of the works " (Dubé, 2012, p.7).

Cainelli et al. (2006) examined the interaction between innovation and performance in more detail and concludes that there is a two-way relationship: innovative firms outperform noninnovators, but the most successful companies are also more likely to innovate and devote more resources to innovation. 
Therefore the evidence on innovation and performance suggests a positive effect on productivity and growth. There is evidence suggesting that external links, in particular with the customers, have a positive impact on innovation (Tether, 2005; Leiponen, 2005) and other evidence showing that innovation positively affects performance.

In addition, some authors found that innovation has a positive effect on the sales growth but not on productivity (Mansury and Love, 2008). However, this finding is in contradiction with the result found by Mairesse and Mohnen (2003) who found that there is a positive relationship between the level of productivity and innovation.

Organizational innovation significantly contributes to the performance, productivity and improvement of new goods and services and hence competitiveness and growth (Mayor, 2003).

Although it is generally accepted that innovation has contributed to the business performance, companies must adopt some types of innovation over time that enable them to achieve a competitive advantage and enhance their performance (Damanpour, 1991; Hénard and Szymnsk, 2001; Porter, 1990).

The organizations that have greater innovation will achieve a better response from the environment, find it easier to improve organizational performance capabilities and consolidate a sustainable competitive advantage (Calantone et al, 2002; Hurley and Hult, 1998; Zaltman et al, 1973). Innovation has a direct impact on organizational performance (Hudges and Morgan, 2007; Zahra et al, 2000).

Some empirical studies indicate that innovation has no influence on business performance (Bierly and Westhead, 1990; Heunks, 1998), whereas others find negative implications on innovation performance (McGee et al, 1995 Vermeulen et al, 2005, p.442, cited by Rosenbusch et al. (2011).

On the other hand, , the likely adverse effects from an orientation of innovation and some contradictory evidence, theory and most empirical studies suggest a positive relationship between organizational innovation and organizational performance (Chen (2006); Damanpour et al, 2009, Eddlestone et al (2008,2009) Liao and Rice, 2010; Nranjo-Gil, 2009 Subrahmanya, 2005; Yam et al .2004, De Carolis and Deeds, 1999, Guo et al, 2005, Atuahene-Gima and Li, 2001, 2002, p.442, cited by Rosenbusch et al. (2011).

$\mathrm{H}(3)$ : There is a positive relationship between organizational innovation and organizational performance.

\section{METHODOLOGY AND MEASUREMENT OF VARIABLES 4.1. The sample}

The sampling of empirical research phases is an essential step to ensure that the population has been correctly identified. This is the first step of the sampling process (Garrity et al, 2005). The parent population is the basis of deciding the sample to investigate. It can be defined as "all objects with the desired information to answer objectives of a study "(Giannelloni and vernette, 1995, p 153).

Out of the 435 companies that were contacted, only 228 returned the questionnaires, 200 of which proved actually usable. Our final sample consists of 200 Tunisian companies. We contacted 158 companies face to face, and 42 companies by e-mail (Following the difficulty of proximity). 
International Journal of Managing Value and Supply Chains (IJMVSC) Vol. 6, No. 1, March 2015

\subsection{Operationalization of variables}

To address this variable, we used different researches, such as those of Lee et al. (1999) and Terziovski and Samson (1999). The respondents were asked to indicate their level of perception on each item of the variables.

- Organizational innovation

Organizational innovation is an independent variable measured by a Likert in five points going from 1 to 5. The codification on proposals is as follows: (1) not implemented, (2) imitated national markets, (3) imitated international markets, (4) The current organizational practices are improved, (5) organizational innovation is implemented.

The items by which this variable is measured were validated and used by the OECD Oslo Manual (2005). This involves the measurement of the elements of organizational innovations implemented in the organization.

- Internal sources of knowledge

The internal sources of knowledge are an independent variable. This variable is measured by six items. The respondents are asked to rate the importance of the potential of internal knowledge in the company using a Likert scale of 5 points from $1=$ very poor to $5=$ very high.

Based on the literature, this variable has been developed by several authors (Bierly and Chakrabarti (1996), Grant (1996), Nevis et al (1995), Zack (1999) where the items by which this variable is measured are inspired (validated and used by from the work of Lee et al. (1999).

\section{- Organizational performance}

Organizational performance is a dependent variable measured by a Likert scale of seven points ranging from $1=$ not at all important to $5=$ very important. This variable is measured by eight items.

Thus, the studies is used several measures of organizational performance. The dilemma which is confronted by researchers is that one performance measure can fully explain all the aspects of organizational performance. In order to address this problem, the researchers resorted to the use of multiple measures of organizational performance.

The measurements of performance depend essentially on the objective and the context of the research. Some of the variables proposed to measure this concept include the sales, market share, profitability, operational efficiency, business growth, competitiveness, customers satisfaction and productivity.

Items 1, 2, 3.4, 5 and 6 are used by the work of Premkumar and King (1994) and items 7, 8 and 9 are inspired by the work of Samson and Terziovski (1999).

\subsection{Data Analysis and Interpretation of Results}

The data were analyzed in several phases. First, the factor analysis (principal component analysis with oblimin rotation) was performed on all the multiple scale items to determine the item retention. The exploratory factor analysis revealed that two of the internal sources of knowledge items, two of the organizational innovation items and two 
of the organizational performance items did not meet our criteria. These items were removed before the final scales were computed by averaging the remaining items. Table 1 reports the results and the summary statistics of all scales.

Table 1.EFA factor loading

\begin{tabular}{|c|c|c|c|}
\hline & $\begin{array}{l}\text { Factor } \\
1\end{array}$ & Factor2 & Factor3 \\
\hline Interne3 &, 023 &,- 071 &,- 862 \\
\hline Interne4 &, 055 & ,038 &,- 823 \\
\hline Interne5 &, 136 & 011 &,- 761 \\
\hline Interne6 & ,014 & , 145 &,- 774 \\
\hline Innovorg2 &,- 062 & ,768 &,- 177 \\
\hline Innovorg3 &, 155 & ,832 &, 175 \\
\hline Innovorg4 & ,214 & ,724 & ,008 \\
\hline Innovorg5 &,- 162 & ,775 &,- 100 \\
\hline Innovorg6 &,- 032 & ,654 &,- 116 \\
\hline Innovorg8 & ,004 & ,763 & ,098 \\
\hline Innovorg9 &,- 022 & ,829 &,- 021 \\
\hline Performance1 & ,901 & ,030 & ,089 \\
\hline Performance 2 & ,879 & ,023 & ,082 \\
\hline Performance 3 & ,846 & ,061 &,- 064 \\
\hline Performance4 & ,762 &,- 014 &,- 080 \\
\hline Performance5 & ,808 &,- 078 &,- 146 \\
\hline Performance6 &, 742 &, 005 &,- 214 \\
\hline Cronbach's Alpha & 0.924 & 0.886 & 0.868 \\
\hline Eigen value & 6.751 & 3.300 & 1.549 \\
\hline
\end{tabular}

To test the model in this study, AMOS 19.0 was used as the statistical tool to test the full measurement model. A two-stage strategy was used: first, confirmatory factor analysis (CFA) was carried out to evaluate the measurement model, and second the full model was tested to generate the path coefficients.

To examine the psychometric properties of the measurement model, Crombach's alpha, convergent validity, and discriminant validity were assessed for the remaining 17 indicators. Crombach's alpha reflects the internal consistent reliability among the indicators of a construct. As seen in Table 1(Table 1.1: EFA factor loading), all the Crombach's exceed 0.8, showing a satisfactory reliability for all the three scales.

A convergent validity is suggested if the factor loadings are 0.60 or higher (Chin et al. 1996, Bagozzi and Yi 1988). We found that the lowest loading was 0.589 which was very close to the ceiling. This finding provides strong support for the convergent validity of the scale. Next, to check the reliabilities of latent variables, CR and AVE were calculated using the procedure outlined by Fornell and Larcker (1981).

As shown in Table 2 (Table 2 :Construct reliability), CRs and AVEs of our scale are above respectively 0.72 and 0.5 , except for the innovation latent variable at 0.482 , but which was nevertheless very close to the ceiling. These results suggested the satisfactory the convergent validity of the measurement model. 
International Journal of Managing Value and Supply Chains (IJMVSC) Vol. 6, No. 1, March 2015

Table 2. Construct reliability

\begin{tabular}{|c|c|c|c|c|}
\hline Construct & Indicator & Loading & $\begin{array}{l}\text { Composite } \\
\text { reliability }(\mathrm{CR})\end{array}$ & $\begin{array}{l}\text { Average } \\
\text { variance } \\
\text { extracted } \\
\text { (AVE) }\end{array}$ \\
\hline \multirow{4}{*}{$\begin{array}{l}\text { Internal sources } \\
\text { of knowledge }\end{array}$} & Interne3 & 0.775 & - & \multirow[t]{4}{*}{0.632} \\
\hline & Interne4 & 0.824 & 11.818 & \\
\hline & Interne5 & 0.794 & 11.368 & \\
\hline & Interne6 & 0.764 & 10.895 & \\
\hline \multirow{7}{*}{$\begin{array}{l}\text { External sources } \\
\text { of knowledge }\end{array}$} & Innovorg2 & 0.813 & 9.140 & \multirow[t]{7}{*}{0.482} \\
\hline & Innovorg3 & 0.804 & 9.073 & \\
\hline & Innovorg4 & 0.752 & 8.660 & \\
\hline & Innovorg5 & 0.713 & 8.314 & \\
\hline & Innovorg6 & 0.630 & - & \\
\hline & Innovorg8 & 0.589 & 7.124 & \\
\hline & Innovorg9 & 0.718 & 8.358 & \\
\hline \multirow{6}{*}{$\begin{array}{l}\text { Organizational } \\
\text { performance }\end{array}$} & Performance1 & 0.696 & - & \multirow[t]{6}{*}{0.622} \\
\hline & Performance 2 & 0.654 & 13.637 & \\
\hline & Performance 3 & 0.775 & 14.778 & \\
\hline & Performance 4 & 0.815 & 10.674 & \\
\hline & Performance5 & 0.882 & 11.438 & \\
\hline & Performance6 & 0.898 & 11.604 & \\
\hline
\end{tabular}

\section{Source: Data from SPSS (18)}

For the discriminant validity, Fornell and Larcker (1981) suggested that the square root of the AVE from the construct should be larger than the correlation shared between the construct and other constructs in the model. Based on Fornell and Larcker's (1981) principle, Chiou and Lin (2009) suggested that the average AVE values of any pair of constructs should be larger than the squared correlation between that pair of constructs. Following this suggestion, the results given in Table 3 (Table 3: Discriminant validity of the theoretical construct measures) indicate that the three constructs have accept the discriminating validity.

Table 3. Discriminant validity of the theoretical construct measures

\begin{tabular}{|l|l|l|l|}
\hline & $\begin{array}{l}\text { Internal sources of } \\
\text { knowledge }\end{array}$ & $\begin{array}{l}\text { Organizational } \\
\text { innovation }\end{array}$ & $\begin{array}{l}\text { Organizational } \\
\text { performance }\end{array}$ \\
\hline Internal source & 0.794 & & \\
\hline $\begin{array}{l}\text { Organizational } \\
\text { innovation }\end{array}$ & 0.404 & 0.694 & \\
\hline $\begin{array}{l}\text { Organizational } \\
\text { performance }\end{array}$ & 0.641 & 0.286 & 0.788 \\
\hline
\end{tabular}

Fig. 1 presents the structural analysis results. As seen in Table 4(Table 4: Goodness-of-fit measures of the research model) the fit values of indexes such, as the RMSEA, TLI, CFI, and GFI, show that the full model fits the sample data. The path coefficients suggest that the internal source of knowledge has a significant impact on performance and on organizational innovation; however the latter has no significant effect on performance. Thus, hypotheses $\mathrm{H} 1$ and $\mathrm{H} 2$ are accepted but $\mathrm{H} 3$ is rejected (Table 5 Summary of testing results hypothesis). 
International Journal of Managing Value and Supply Chains (IJMVSC) Vol. 6, No. 1, March 2015

Table 4.Goodness-of-fit measures of the research model

\begin{tabular}{|l|l|l|}
\hline Goodness-of-fit measure & Recommended value & Fit index \\
\hline $\mathrm{X}^{2} /$ degree of freedom & $<=5.00$ & 2.226 \\
\hline Goodness-of-fit index (GFI) & $>=0.90$ & 0.882 \\
\hline Adjusted goodness-of-fit index (AGFI) & $>=0.80$ & 0.839 \\
\hline Tucker-Lewis index (TLI) & $>=0.90$ & 0.926 \\
\hline Comparative fit index (CFI) & $>=0.90$ & 0.939 \\
\hline Root mean square residual (RMSR) & $<=0.10$ & 0.078 \\
\hline
\end{tabular}

Table 5. Summary of testing results hypothesis

\begin{tabular}{|l|l|}
\hline Hypothesis & Standardized Path Coefficients \\
\hline $\begin{array}{l}\text { H1: Internal sources of knowledge } \\
\text { Organizational Innovation }\end{array}$ & 4.643 \\
\hline $\begin{array}{l}\text { H2: Internal sources of knowledge } \\
\text { Organizational performance }\end{array}$ & 6.698 \\
\hline $\begin{array}{l}\text { H3: Organizational Innovation } \\
\text { Organizational performance }\end{array}$ & Not supported \\
\hline
\end{tabular}

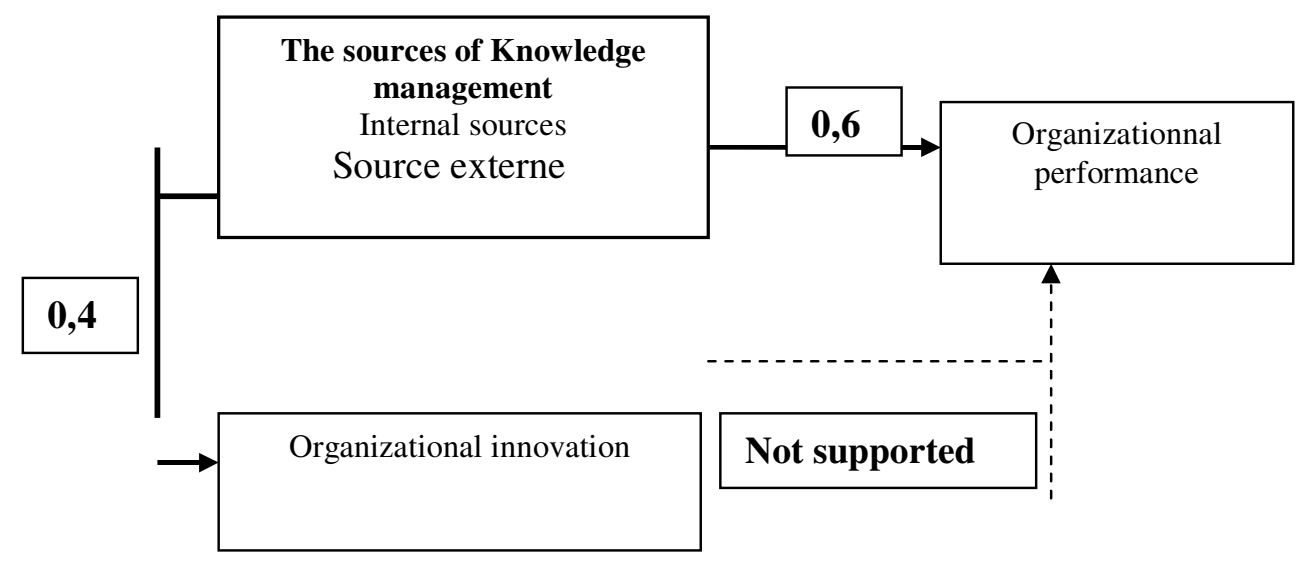

Figure 1: Conceptual model of the research

\section{DISCUSSION}

The importance of knowledge management for organizations has been widely discussed in recent years. Chronologically, organizational knowledge is generated internally (Paul, 2012). According to the OECD (2005), organizational innovation is nothing but the company's adoption of new ways to produce. Today, only a few companies can sustain their competitiveness and innovation by focusing solely on the internal sources of knowledge. Very specific customer knowledge management, technology, markets, etc are the key to innovation (Paul, 2012). The relationship between knowledge and innovation has long been recognized.

The results of the confirmatory analysis of our research enabled us to validate our first research hypothesis .It is a relationship between the internal sources of knowledge and organizational innovation, with a correlation coefficient $\mathrm{CR}=4,643>1.96$ and $\mathrm{p}=0,000<0,05$ 
Our results are consistent with those of Cassiman and Vengelers (2006) who showed that there is a relationship between the internal sources of knowledge and organizational innovation.

Thus, in the Tunisian context, to innovate, companies must rely on these internal knowledge bases and enjoy them. In addition, the ability to integrate external knowledge and process this information enables the creation of new knowledge; that is the qualified internal competence of companies. Internal knowledge consists of qualifications, skills and experience of the staff and the knowledge placed in the process, in the organization, and in the databases. Certainly, the Tunisian companies promote and give much importance to internal knowledge lying within the organization for external knowledge of the various external actors. Therefore, internal knowledge is a basic source for the company.

Huber (1991) states that knowledge residing within the company cannot be acquired. Such knowledge is the experience that can be discussed, and can be objective.

The results of the confirmatory analysis of our research who enabled us to validate, our first research hypothesis with a correlation coefficient $C R=6.698>1.96$ and $p=0,000<0,05$.

Other works, namely, those of Slater and Narver (1995), give more importance to the internal sources of knowledge. These authors propose that effective managers use several internal sources to gain new insights for their businesses and for their environment. In fact, companies can develop knowledge by collecting pieces of information they get from other internal units.

In our research, companies give more importance to the internal sources of knowledge. This is explained by the experience of the various officers and employees. Indeed, they try to exploit and use their own information to achieve their set goals and improve organizational performance.

In addition, performance depends on the ability of the organizations to incorporate their resources to encourage the collaboration between the actors and facilitate communication and access to information.

In the Tunisian companies focusing on the effective use of the internal sources of knowledge, it is possible to obtain a competitive advantage by supplying other businesses which are more profitable and grow their businesses, etc.

Traditionally, business leaders are tied to organizational performance; hence the interest of researchers' focus is on this issue. Indeed, a company has a competitive advantage when it has the resources or skills that are unique and difficult to imitate and which enable it to provide higher customer's value. Some authors consider that this competitive advantage is possible through continuous innovation in an organization (Christensen, 2001; Porter, 1996, cited by Bochémier 2006)).

The results of our research have not validated our third hypothesis. The results of our research are inconsistent with the results of other studies focus on the positive relationship between organizational innovation and organizational performance resulting in increased performance (Deshpande et al., 1993; Dos Santos and Peffers, 1995; McGrath et al, 1996 andFu Gao, 1996; Han et al., 1998; Schwab and Olson, 2000; Hult andKetchen, 2001; Du and Farley, 2001; Calantone et al., 2002; Garg et al., 2003; Wu et al., 2003).

Our research coincides with previous research that has shown that there is no relationship between organizational innovation and organizational performance (Capron (1999) and Heshmati (2002).

Therefore, in the Tunisian context, companies pay more attention to organizational innovation. This is explained by several things. 
First, most of the Tunisian companies do not have specific departments to research and development. Thus, Tunisian companies apply organizational structures in accordance with the standards of the country. Second, given the lack of investment in innovation. Indeed, there is a difficulty to change and easily innovate the methods of the company's management practices in the work organization or external relations expertise strategies cooperation or alliance, tools, processes, organizational and managerial techniques to improve organizational performance.

Usually, firms innovate at the organizational level depending on the priorities they define. They do so by applying a series of minor changes to their problem based emergencies. Certainly, renewals at the organizational structure facilitate teamwork and coordination between the different functions of the company.

\section{CONCLUSION, LIMITATIONS AND FUTURE RESEARCH}

We have to appreciate that organizational performance is an essential engine of the firms' activity of innovation. Moreover, innovation can lead to the development of specific strategic resources for the company; provide a competitive advantage and high performance which could helps to reinvestment in innovation to gain a competitive advantage .The empirical verification of these proposals is to confirm or refute the assumptions previously made by administrating a questionnaire to Tunisian companies and analyzing and processing the data using appropriate statistical tools. We found that there is a relationship between organizational innovation and organizational performance. The results obtained through the interrogation of 200 companies in our research test the causal structure of the overall research design and result in theoretical contributions, methodological and practices to be exposed.

The first contribution is theoretical order who is interested in the originality of our research justified by the lack of research that processed the enrichment explanation of the problems connected between the internal sources of knowledge management, innovation organizational and organizational performance.

The second methodological contribution is the development of a set of scales of valid and reliable measures. Indeed, on the basis of previous empirical work, we operationalized three variables (internal sources of knowledge, external sources of knowledge and organizational performance). We also note the limitations of our study. Finally, we assign a set of reflections that we have shown as extensions and paths for future research.

The first limitation focuses on the empirical study of different businesses and sectors. Moreover, conducting a study in different industries helps control certain specific circumstances, especially in the organizational performance of the company. However, this can limit the scope of the results, their extension to other contexts, and thereafter the external validity of the research.

On the other hand, we identified some methodological problems, such as data collection. The fact that this research is based largely on the perception of different managers of firms covered with subjectivity, leads to more generalized results. This approach could cause some bias since most of the data required to measure the variables are intangible in nature, therefore it would be difficult and even impossible, to collect the data objectively.

Highlighting the theoretical and methodological limitations to this research shows that the achievement of other researches reform the current system of research. In addition, to the different lines of research proposed to overcome the various inherent limitations of this research, other possible extensions can be considered. They should be varied and concern both theoretical insights and methodological improvements. 
International Journal of Managing Value and Supply Chains (IJMVSC) Vol. 6, No. 1, March 2015

The line of research would examine the external validity of this work. Indeed, it would provide, as part of further work to re-check our model on a single industry, to check whether our results are generalizable or not. Thus, the use of research as a field operating on a homogeneity of private and public companies in a single industry with using the internal sources of knowledge management to improve innovation and organizational performance, and to undertake on the significance of our results.

Finally, it can be left room for other variables in our future research. For this, it exhibits several advantages, creates homogeneous groups and allows you to be more efficient to submit faster. Again, we will encourage ordering objective measures with subjective measures to improve the validity of results.

\section{REFERENCES}

1. Argyris et Schon, D. (1978) Organizational learning: A theory of action perspective, Reading.MA: Addison-Wesley.

2. Bagozi et Yi Y. (1988) "On the Evaluation of Structural Equations models". Journal of the Academy of Marheting Science . 74, pp94-16.

3. Bierly et Chakrabarti A. (1996) "Generic knowledge strategies in the U.S. pharmaceutical industry". Strategic Management Journal . vol .123,pp135-17.

4. Bohémier, Sophie, (2006) La performance organisationnelle par l'intégration de l'orientation marchée et l'orientation innovation. Université du Québec A Montréal.

5. Cainellei et al. 2006 "Innovation and economic performance in services: a firm-level analysis", Cambriage Journal of Economics .vol. 435, pp458-30.

6. Cameron K. (1986) Effectiveness as paradox: consensus and conflict in conceptions of organizational effectiveness. Management Science. Vol.539, pp53-32.

7. Calantone et al. (2002) "Learning orientation firm innovation capability and firm prrformance",.Industrial Marketing Management .vol.515,pp524-31.

8. Cassiman B et Vengelers R. (2006). "In search of complementarity in the innovation strategy: internal R\&D and external knowledge acquisition". Management Science, vol.68, pp82-52.

9. Chakravarthy B. (1986) «Measuring strategic performance", Strategic Management Journal, vol.437, pp58-7.

Chen S etChen A. (2006). "Knowledge management performance evaluation: a decade review from 1995 to 2004". Journal of Information Science, voL17, pp38-32.

10. ChinW Et al. (1996) A Partial Least SquaresLatent Variable Modeling Approach for Measuring Interaction Effects: Results from a Monte Carlo Simulation Study and Voice Mail Emotion/Adaptation Study. Proceedings of the Seventeenth International Conference on Information Systems 21:41. Cleveland: Ohio.

11. Chiou H et Lin P. (2009) Principles and Application of Structural Equation. China: Beijing:China light Inustry Press.

12. Damanpour F et al. (1989) "The relationship between types of innovation and organizational performance".Journal of Management Studies ,vol. 587, pp 601-6.

13. Damanpour F et al. (2009). "Combinative effects of innovation types and organizational performance: a longitudinal study of service organizations". Journal of Management Studies , vol.650, pp 675-64.

14. Damanpour F et al. (1998) Theories of organizational structure and innovation adoption: the role of environmental change.Journal of Engineering and Technology Management. vol.1, pp24-15.

15. Dewar R et Dutton J.E. (1986) "The adoption of radical and incremental innovations: An empirical analysis". Management Science .vol.1422, pp1433-32.

16. Dozi G. (1998).Sources, procedures and microeconomic effect of innovation.

17. Drucker P. (1993) Au-delà du capitalisme : La métamorphose de cette fin de siècle,. Paris: Dunod.

18. Dubbé C et al. (2012).L'innovation: définitions et concepts. Québec.

19. Eddleston K. (2008) "Resource configuration in family firms: linking resources, strategic planning and technological opportunities to performance". Journal of Management Studies, vol.26, pp50-45. 
20. Fornell C et larcker D. (1981) "Evaluating Structural Equation Models with Unobservable Variables and Measurement Error: Algebra and Statistics". Journal of Marketing Research, vol.39, pp50-18.

21. Freeman C. (1991) "Networks of Innovators: A Synthesis of Research Issues", Research Policy ,vol. 499, pp514-20.

22. Grant R, (1996) "Toward a knowledge -Based Theory of the firm", Strategic Management Journal, vol.109, pp122-17.

23. Gunday G, (1986). "Effects of innovation types on firm performance". International Journal of Production Economics, vol.662, p676.

24. Gunday G et Dutton J. (2011) Effects of innovation types on firm performance. International Journal o Production Economics, vol.662, pp676-13.

25. Hamel G. (2006) The why, what, and how of management innovation. Harvard Business Review, vol. 72, pp84-84.

26. Hamel G, (2007) The future of management, Boston, Harvard Business school Press.

27. Hamel G, 2009. Management innovation Leadership Excellence.p26.

28. Henard D et Szymanski D. (2001) "Why some new products are more successful than others",.Journal of Marketing Research , vol.362, pp375-38.

29. Huber G.P. (1991). Organizational Learning: The Contributing Processes and the Literatures. Organization Science, vol.88, pp115-2.

30. Hudges M et Morgan R. (2007) "Deconstructing the relationship between entrepreneurial orientation and business performance at the embryonic stage of firm growth". Industrial Marketing Management, vol.651, pp61-36.

31. Hult, G.T.M., Hurley, R.F. \& Knight, G.A. (2004) "Innovativeness: its antecedents and impact on business performance”, Industrial Marketing Management, vol. 33, pp. 429-38.

32. Hurley R et Hult G. (1998) "Innovation, market orientation, and organizational learning: An integration and empirical examination". Journal of Marketing, vol.42, pp54-62.

33. Igalens J et Gond J.P. (2003) "La mesure de la performance sociale de l'entreprise: une analyse critique et empirique des données ARESE".Revue française de Gestion des Ressources Humaines, vol.111, pp130-50.

34. Jacquet, S. (2011) Management de la performance : deux concepts aux outils. 6.

35. Katila, R .(2002) "New product search overtime: past ideas in their prime?". Academy of Management Journal, vol. 995, pp1010-45.

36. Knight, K.E. (1967) "A Descriptive Model of Intra-firm Innovation Process", in Huat. Ong.c et lee, F. (2005), "Determinants of Firm Innovation in Singapore. Technovation, vol.261, pp268-25.

37. Leiponen, A. (2005) "Organization of Knowledge and innovation: the case of Finish business services". Industry and innovation, vol.185, pp203-12.

38. Le Conollier, C. (2009) Innovation sociale entre théorie et pratiques ; synthèse de la conférence, Chambre Régionale de l'Economie Sociale et Solidaire de Base -Normandie en partenariat avec l'HFR de sciences économiques et de gestion de l'université de CAEN Basset Normandie et la région Basse -Normandie.

39. Lichtenthaler, U. (2009) "Absorptive Capacity, Environmental Turbulence, and the Complementarity of Organizational Learning Processes". Academy of Management Journal , vol.822, pp846-52.

40. Luecke, R \& Katz, R (2003) “Managing Creativity and Innovation”, Harvard Business School Press, MA.

41. Mairesse J et Mohnen P. (2003) R\&D and productivity: a re-examination in light of the innovation surveys. DRUID Summer Conference, vol.12, p14. Copenhagen.

42. Mansury J et al. (2008) "Innovation, productivity and growth in US business services: A firmlevel analysis".Technovation, vol.52, pp62-28

43. Meyer, C. (1993) Fast cycle time: How to align purpose,strategy and structure for speed. New York : Free Press.

44. Mol M et Birkinshan J. (2009) "The sources of management innovation: When firms introduce new management practices",Journal of Business Research, vol.1269, pp1280-62.

Morin E. Et al. (1994) L'efficacité de l'organisation : théories, représentations et mesures. Montréal Gaetan Morin .

45. Nanaka I et Takeuchi H.(1997) La connaissance créatrice : La dynamique de l'entreprise apprenante,. De boeck Université. 
International Journal of Managing Value and Supply Chains (IJMVSC) Vol. 6, No. 1, March 2015

46. Neely A et Hii J. (1998) Innovation and business performance: A literature Review, The Judge Institute of Management Studies, University of Cambridge.

47. Nevis C. et al. (1995) "Understanding organizations as learning systems". Sloan Management Review, vol.73, p85.

48. Nonaka, I. (1994). " Dynamic theory of organizational knowledge creation". Organization Science, vol.14, pp38-5.

49. Nonaka I et Yamanouchi T. (1989). "Managing innovation as a self-renewing". Journal of Business Venturing, vol.299, pp315.

50. OCDE. (2005). Manuel d'OSLO, principes directeurs pour le recueil et l'interprétation des données sur l'innovation.

51. Parry M et Gualti R. (1996) "Is slack goog or bad for innovation". Academy of Management Journal, vol.1245, pp1264-39.

52. Paul, K. (2012) The role of external knowledge in open innovation- A systematic Review of literature. Proceedings of the European Conference on Knowledge Management, p592.

53. Penrose E. (1959).The Theory of the growth of the Firm. London: Basil Blackwell.

54. Phene A. et al. (2006) "Breakthrough innovations in the US bio-technology industry: the effects of technological space and geographical origin". Strategic Management Journal. Vol, pp 388-27.

55. Robinson, W. (1990) "Innovation and start-up business market share performance".Management Science, vol.1279, pp1289-36.

56. Robinson, W. (1988) "Source of market et pionner advantages: the case of industrial goods industrial goods industries".Journal of Marketing Research, vol.87, pp94-25.

57. Rosenbusch, B. et al. (2011) "Is innovation always beneficial? A Meta analysis of the relationship between innovation and performance in SMEs", Journal of Business Venturing , vol.442-26.

58. Rosenthal, S. (1992). Effective product design and development. Homewood: IL:Irwin.

59. Rosenkopf L. et A Nerkar. (2001) "Beyond Local Search: Boundary-Spanning, Exploration, and Impact in the Optical Disc Industry".Strategic Management Journal, vol.287, pp306-22.

60. Rothweell, R. (1992) "Successful industrial innovation: critical factors for the 1990s",R\&D management, vol.221, pp39-22.

61. Sayem, M. (2012) Values orientation in business through service innovation: A conceptual framework, International Journal of Managing Value and Supply Chains (IJMVSC) Vol. 3, No. 4, December 2012.

62. Schmpeter, J. (1934) Theory of Economic Development : An enquiry into profits, Capital n Interest and the business cycle. Harvard University, Cambridge, MA: Press .

63. Slater, S. (1995) "Market Orientation and the Learning ", Journal of Marketing .63:74-59.

64. Soo C. et al. (2002) "Knowledge Management : philosophy, processes and pitfalls ".California management Review, vol.129, pp150-44.

65. Teece, D. (1989) "Inter-organizational requirements of the innovation process", Managerial and decision Economics, vol.35, p42.

66. Tether, B. (2005) "Who co-operates for innovation and why an empirical analysis", Research policy, vol.947, pp967-31.

67. Thompson, V. (1965) "Bureaucracy and innovation administrative", Science Quarterly .1:8-10.

68. Tidd, J. et al. (2005). Managing innovation: Integrating technological, market and organizational change. John Wiley \& Sons Inc.

69. Utterback J et Abernathy, W. (1975) "A dynamic model of process and product Innovation". Omega.vol. 639, pp656-3.

70. Venkatraman N et Ramanujam V. (1986) "Measurement of business performance in strategy research: a comparison of approaches". Academy of Management Review. Vol.801, pp814-11.

71. Wengel J and Lay G. (2000) Surveying Organizational Innovation on a European Level: [Challenges and Options. Fraunhofer Institut für System- und Innovations forschung, Karlsruhe.

72. Wheelwright K et Clarck S. (1992) Revolutionizing product development: quantum leaps in speed, efficiency and quality. New York: The Free Press.

73. Wolfe, R. (1994) "Organizational Innovation: Review, Critique and Suggested Research Directions". Journal of Management Studies.405:431-31.

74. Zahra, S. et al. (2000) "International expansion by New Venture firms: international diversity, mode of market entry, technological learning and performance ".Academy of Management Journal , vol. 925, pp950-43. 
International Journal of Managing Value and Supply Chains (IJMVSC) Vol. 6, No. 1, March 2015

75. Zaltman, G. (1999) "Relationships between Providers and Users of market Research: the Dynamics of Trust Within and Between Organization". Journal of Marketin Research , vol.314, pp328.29.

76. Zaltman, G. et al. (1973) Innovations and organizations. New York: Wiley.

77. Zammuto, R. (1984) "A comparison of multiple constituency models of organizational effectiveness". Academic Management Review, vol. 606, pp16-9.

\section{ACKNOWLEDGEMENTS}

Dear $\mathrm{Mr}$ the responsible of "International Journal of Managing Value and Supply Chains (IJMVSC)", Thank you very much to giving me the authorization of publishing my article in your journal with all my gratitude.Best regards.

\section{Authors}

[Rim Maâlej Ben Zaied] Bachelor of Science in Economics and Management (2005), MBA from the Higher Business Administration at Sfax (2009), master's degree in management and internationalization of economies with the FSEGS (2011) Institute for Training Araba Bank of Tunisia in the International division South (foreign service) (2008), First registration for the preparation of a thesis in science management FSEGS (2012-2013), temporary assistant to higher business school Sfax (ESC) (2012), participation in several conferences and scientific publications (2013-2014).

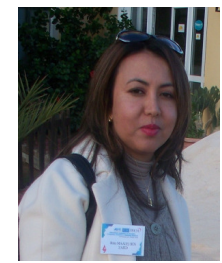

[Hanène Louati Kaaniche] Baccalaureate in Mathematics. High Pilot School of Sfax (Tunisia) (2013), POSTGRADUATE DIPLOMA In Trading Higher Studies. High Business School of Sfax. University of Sfax(2005), Master in management science, option: Human Resource Management, High Institut of Mnagement. University of Tunis (2008), Ph.D. in management Science, at FACULTY OF ECONOMICS AND MANAGEMENT OF SFAX. University of Sfax (2013).

[Affes Habib] Lecturer (HDR) Management Sciences (FSEG - University of Sfax - Tunisia); co-founder of the center of entrepreneurial activities at the University of Sfax - Tunisia; Training of trainers responsible business practices with the Agence Universitaire de la Francophonie (AUF); co-founder of the laboratory Lartige (Research Laboratory of information technology, governance, entrepreneurship. at the Faculty of Economics and Sfax-Tunisia management), director of doctoral theses and Masters memories in Management, President of the Tunisian Association for research in Management Sciences; and now (Associate professor of business administration in the faculty of business administration at Jazan University in the Kingdom of Saudi Arabia), referee in several scientific journals. 